\title{
Eenheid of verscheidenheid
}

Citation for published version (APA):

Vroom, C. W. (1995). Eenheid of verscheidenheid. Universiteit Maastricht. https://doi.org/10.26481/spe.19951013cv

Document status and date:

Published: 13/10/1995

DOI:

10.26481/spe.19951013cv

Document Version:

Publisher's PDF, also known as Version of record

\section{Please check the document version of this publication:}

- A submitted manuscript is the version of the article upon submission and before peer-review. There can be important differences between the submitted version and the official published version of record.

People interested in the research are advised to contact the author for the final version of the publication, or visit the DOI to the publisher's website.

- The final author version and the galley proof are versions of the publication after peer review.

- The final published version features the final layout of the paper including the volume, issue and page numbers.

Link to publication

\footnotetext{
General rights rights.

- You may freely distribute the URL identifying the publication in the public portal. please follow below link for the End User Agreement:

www.umlib.nl/taverne-license

Take down policy

If you believe that this document breaches copyright please contact us at:

repository@maastrichtuniversity.nl

providing details and we will investigate your claim.
}

Copyright and moral rights for the publications made accessible in the public portal are retained by the authors and/or other copyright owners and it is a condition of accessing publications that users recognise and abide by the legal requirements associated with these

- Users may download and print one copy of any publication from the public portal for the purpose of private study or research.

- You may not further distribute the material or use it for any profit-making activity or commercial gain

If the publication is distributed under the terms of Article $25 \mathrm{fa}$ of the Dutch Copyright Act, indicated by the "Taverne" license above, 


\section{ME \\ VAB \\ 953}

\section{Eenheid of verscheidenheid}

een pleidooi voor verscheidenheid van theorie over management en organisatie en tegelijk ook voor tact en tolerantie

\section{Rede}

uitgesproken bij de aanvaarding van het ambt van deeltijds hoogleraar Comparative Management aan de Faculteit der Economische Wetenschappen, Rijks-universiteit Limburg te Maastricht, op vrijdag 13 oktober 1995

door

\section{Casper W. Vroom}

Deze uitgave is mede mogelijk gemaakt door

Wagenaar, Hoes \& Associés, organisatieadviseurs te Utrecht 


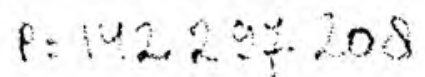

Universiteitsbibliotheek

Rijksuniversien: Limburg

2 


\section{Dames en Heren,}

\section{SPROOKJES EN COMPARATIVE MANAGEMENT}

"Heel wat jaren geleden leefde er een keizer, die zo vreselijk veel van mooie, nieuwe kleren hield, dat hij al zijn geld uitgaf om toch maar mooi gekleed te zijn" (Andersen, 1952, 73). Zo begint de sprookjesverteller Hans Christiaan Andersen zijn verhaal over de nieuwe kleren van de keizer. Hij en zijn collega's nemen u mee naar de keizer van China, naar de steppen van Rusland, naar een koude avond in Kopenhagen. Ze brengen een interessante mengeling van verzinsel en waarheid. Sprookjes zijn immers niet echt gebeurd. Maar sprookjesvertellers doen wel verhalen waar $u$ wat van leert. Ze proberen uw gevoelige snaar te raken. Ze hebben kennelijk goed rond gekeken in de wereld, zoals ook de blinde dichter dat benadrukt van zijn held Odysseus: hij, die zoveel steden en mensen bezocht en hun geest leerde kennen (Homerus, z.j.). En ze zijn in staat hun ervaringen met andere mensen zo onder woorden te brengen dat $u$ achteraf denkt: $i k$ ben er toch een tikje wijzer van geworden.

De wetenschap en haar beoefenaren hebben de naam wat droog te zijn. Ik wil dat vanmiddag vermijden. Mijn opdracht aan deze universiteit leent zich daar uitstekend voor: studenten laten kennis maken met de grote variëteit van de manieren waarop mensen vormgeven aan hun gedrag in organisaties en daarover vantevoren of achteraf nadenken. Het is volgens mij verstandig studenten daar tijdig op voor te bereiden. Want in de grote wereld, in China, in Rusland, in Kopenhagen kom je de vreemdste mensen en gewoontes tegen. Dan is het goed om te weten hoe dat in elkaar zit en hoe je je moet gedragen. In die zin heeft de wetenschapsbeoefenaar aan een universiteit dus ook een nevenopdracht, niet alleen vertellen hoe de wereld er uit ziet, maar ook zijn studenten uitdagen tot beoordeling, eerst van zichzelf en dan pas van anderen (1). En dat zou moeten leiden tot enige terughoudendheid, tot tact in de omgang met mensen die andere opvattingen hebben en ook tot tolerantie. Het gaat er tenslotte toch om dat wij een menswaardige samenleving weten te realiseren, waarin - binnen grenzen - plaats is voor heel verschillende mensen en hun manieren van denken en doen. Het verschil met de sprookjesverteller is dus maar klein. 
Ik begin daarom met $u$ een aantal verhalen te vertellen. Ik kan $u$ verzekeren dat ze waar gebeurd zijn: ik was er namelijk zelf bij. En ik wil ze $u$ zo vertellen dat $u$ denkt: hicr is vast meer aan de hand. Ik laat $u$ dan vervolgens zien, met behulp van onderzoek van anderen, hoe extreem in sommige gevallen mensen vormgeven aan hun gedrag in organisaties. Ik verken daarmee met $u$ het onderzoeksveld van Comparative Management, want dat is de naam van mijn opdracht aan deze universiteit. In het eerste deel vertel $i \mathrm{k} u$ dus verhalen die berusten op feitelijke ervaring, van mij en van anderen.

Ik zou mijn taak als wetenschapsbeoefenaar verloochenen als ik $u$ daarna niet zou confronteren met de vraag hoe wij het materiaal voor zulke verhalen bij elkaar krijgen en verwerken. We moeten immers weten wat de valkuilen zijn van onze manier van denken, onderzoeken en onderwijzen. In het tweede deel spreek ik daarom over de methodologie van dit vak.

Dat is echter onvoldoende om mijn verhaal van vanmiddag af te sluiten. Ecn goede verteller moct $\mathrm{u}$ immers het gevoel geven dat $\mathrm{u}$ toch wat heeft geleerd... Ik wil daarom tenslotte met u nagaan wat we zouden kunnen hebben aan deze inzichten. En ik kan u nu al vertellen dat ik daarbij twee pleidooien wil houden: één voor het instandhouden van de verscheidenheid van organisatorische theorie over management en organisatic en daarmee de noodzaak om voortdurend te blijven leren en cen ander, voor mij even belangrijk pleidooi, voor tact en tolerantie in de omgang met mensen die geloven in hun eigen organisatorische oplossingen. Dat wordt dan het derde en laatste deel. 


\section{EEN TOUR DE HORIZON IN VERHALEN}

Ik begin dus met $\mathrm{u}$ enkele verhalen te vertellen. Ik mag aannemen dat $\mathrm{U}$ weet wat leiderschap is en ook dat daar nogal wat onderzoek naar gedaan is. In een rommelige straat in Noord-Jakarta, de hoofdstad van Indonesië, ligt een kleine margarinefabriek. Dat is goed te zien en te ruiken want het afvalwater wordt gewoon via de sloot geloosd. Er werken zo'n 150 mensen. De directeur is een "non-pribumi", wat letterlijk vertaald betekent "geen zoon van het land", in gewoon Nederlands "Chinees" en in gewoon Indonesisch een weliswaar rijke, maar toch nog altijd tweederangs staatsburger. Zijn familie woont immers pas sinds de tweede helft van de vorige eeuw in Indonesië. Deze fabriek levert een uitstekende kwaliteit margarine op basis van palmolie, beter zelfs dan het produkt van een bekende Nederlands/Engelse multinational. Op de universiteit waar ik werk, heb ik een project opgezet om met lokale studenten vergelijkend onderzoek te doen bij deze fabriek, een vestiging van een andere Nederlandse multinational en bij een van de betere ziekenhuizen in de stad. Wij gebruiken daarbij drie meetinstrumenten: we onderzoeken de structuur van de organisatie, we brengen het planningsproces in kaart en we hebben een vragenlijst over leiderschap ontworpen voor de medewerkers. De directeur van de margarinefabriek vindt deze academische belangstelling voor zijn kleine bedrijf reuze interessant, maar wil toch even wel precies weten wat wij gaan onderzoeken. "Onderzoek naar de structuur en het planningsproces geeft voor mij geen enkel probleem", zegt hij, "maar die vragenlijst naar leiderschap zie ik niet zo zitten: ik ben namelijk de enige leider in het bedrijf en anders komen de mensen maar op slechte gedachten". $W_{i j}$ kunnen niet anders dan ons verbazen...

Ik vertel $u$ nog een verhaal. U heeft vast een gefundeerde en dus sociaal aanvaardbare opvatting over het belang van werk en carrière maken en wat daar zoal bijhoort, zoals het verschil tussen mannen en vrouwen op dat punt. Ergens in de uitgestrekte steenwoestijn van Tokyo in Japan staat een gebouw dat zich architectonisch niet van de andere onderscheidt en daarom met het Japanse adresseersysteem niet zo gemakkelijk te vinden is. Japanners geven namelijk aan in welke wijk, in welk blok en in welk subblok hun pand ligt. Dat is nog wel uit te zoeken. Maar het laatste nummer verwijst naar de volgorde van gereedkomen van het bouwwerk. De postbode heeft daar geen probleem mee: hij heeft het bouwen zelf zien gebeuren, want veel oude gebouwen zijn er immers niet in Japan. Voor ons als vreemdelingen is dat toch iets 
lastiger. Maar we zijn tenslotte aangekomen in het gebouw van Nikkeiren, het Japanse equivalent van de Nederlandse Stichting van de $\mathrm{Ar}$ beid. We filosoferen na een interview over de opzet en werkwijze van Nikkeiren nog wat na. "Ja", laat een van onze gesprekspartners zich ontvallen, "dat met die vrouwen op de Japanse arbeidsmarkt, dat valt niet mee. Wij mannen zijn heel sensitief voor de gevoelens van onze collega's. Wij mannen moeten immers samen de problemen oplossen en innovaties bedenken. Je begrijpt wel dat 's avonds uitgaan daarbij hoort. Dat schept de sfeer waarin je open met elkaar kunt praten. Vrouwen zijn heel anders. Die moeten 's avonds op tijd thuis zijn om voor de kinderen te zorgen. Die gaan dus niet mee naar de bar en zijn heel hard en zakelijk ingesteld. Ze willen voortdurend tempo maken en nemen niet de tijd om de problemen eens rustig van alle kanten te bekijken. En daarom kun je er niet zo goed mee samenwerken en maken ze dus ook minder kans op een voorspoedige carrière. Wij mannen nemen daar gelukkig nog steeds de beslissingen over..." Dat klinkt toch anders dan we in het Westen gewoon zijn...

Andere tijd, andere plaats, ander decor. Mei van dit jaar, Buffelspoort in het voormalige Zuid-Afrikaanse thuisland Boputhatswana, Bop voor de insiders, een vakantie- en congrescentrum van de Afrikaner Vereniging voor Taal en Kultuur. De top van de nieuwe Zuid-Afrikaanse Politie Dienst zit daar bij elkaar als deelnemers aan een leergang ter ontwikkeling van hun leidinggevende kwaliteiten. $U$ kunt zich vast voorstellen dat er na de algemene verkiezingen in Zuid-Afrika van april 1994 wel enige aanleiding is om de kwaliteit van dat leidinggeven onder de loep te nemen. De minister van Veiligheid en Securiteit, een zwart lid van het ANC en nu verantwoordelijk voor de politie, is erbij en opent de leergang met een aansporing tot openheid en eerlijkheid. "Goh", zegt een van de commissarissen tegen de minister als het officiele gedeelte achter de rug is, "Sydney, hoe lang is het ook al weer geleden dat ik jou gevangen heb gezet?" En er is geen spoor van bitterheid in de reactie van de minister: "ach, ik weet het zelf ook niet meer, was het nu vijf of zes jaar geleden? Maar ik ben toen wel interessante mensen tegengekomen, en daar heb ik veel van geleerd". En beiden lachen hartelijk om die goede oude tijd.

Er begint zich bij $u$ al een beeld af te tekenen van wat mijn leeropdracht aan deze universiteit inhoudt: je komt nog eens ergens en je maakt rare dingen mee. Maar ik geef $u$ naast dat wat badinerende 
motto ook een wat formelere omschrijving mee, omdat die van belang is voor het volgende deel van mijn betoog. Comparative Management is voor mij de vergelijkende bestudering van de menselijke kant van verschillende stelsels van organisatie en leidinggeven. De verschillen die de moeite van het bestuderen waard zijn, kunnen met behulp van minstens drie dimensies in kaart worden gebracht:

- de tijd: mensen hebben in de loop van de geschiedenis andere betekenissen gegeven aan hun werk; wij moeten dus zicht ontwikkelen op de dynamiek van menselijke verhoudingen in en rond organisaties;

- de institutionele context: mensen werken op verschillende manieren in verschillende maatschappelijke contexten; wij moeten dus de verschillen, en natuurlijk ook de overeenkomsten in vormgeving aan en leiding in het oog houden van organisaties in onderscheiden maatschappelijke sectoren als bijvoorbeeld het onderwijs, de gezondheidszorg, het bedrijfsleven;

- de internationale context: mensen werken in verschillende landen op verschillende manieren; wij moeten dus attent zijn op de verschillende manieren waarop mensen vormgeven aan organisaties als we van het ene land naar het andere gaan.

$U$ hoort mij vooral nadruk leggen op de diversiteit van soorten organisaties en de mensen daarin. Ik kom daar straks nog op terug. Voor het moment volstaat de vaststelling dat mensen historisch, institutioneel en internationaal gezien allerlei oplossingen hebben ontwikkeld voor de problemen die uit hun onderlinge samenwerking voortvloeien. En ik ben van menting dat wij veel kunnen leren van deze verscheidenheid van oplossingen. Organisaties zijn immers als het ware samengebalde leerervaringen van mensen, waarin een rijke schat ligt opgeslagen. In het gunstigste geval versnelt deze rijkdom het ontwikkelen van nieuwe oplossingen voor nieuwe problemen omdat mensen verder bouwen op het bestaande en soms ook uitdrukkelijk nieuwe wegen inslaan. Het kan ook gebeuren dat deze ervaringen het ontwikkelen van nieuwe oplossingen voor nieuwe problemen in de weg staan omdat mensen soms teveel vasthouden aan de eenmaal verworven denkramen. Het gaat dus om een kritische benadering van het eerder en elders geleerde: dat is op zichzelf weer de kern van het menselijk leerproces. Daaruit kunnen toevoegingen worden gedaan aan de kennisvoorraad, waarover mensen en organisaties beschikken om te interageren met hun omgeving, zoals Van den Broeck $(1994,89)$ dat zegt. Het is niet voor niets 
dat er tegenwoordig veel aandacht wordt besteed aan het thema van de lerende organisatie. We moeten dat wel goed begrijpen: mensen en organisaties die leren, doen dat om oplossingen te vinden voor hun problemen. Het gevolg daarvan is waarschijnlijk dat mensen, juist vanwege de historische, institutionele en internationale verschillen, allerlei soorten oplossingen bedenken en toepassen. En dat is goed. Ik voel me namelijk wat onrustig als ik zie hoe sommigen in het veld van theorie en praktijk over organisatie en management krachtig onderstrepen dat hun manier van probleemoplossen eigenlijk de enig denkbare en daarom de beste is (2). Zo'n stellingname verhindert verder leren. Deze onrust vormt ook de aanleiding voor mijn pleidooi voor verscheidenheid van theorie, waar ik straks nog op terugkom.

Voordat ik u nu weer een verhaal vertel, voeg ik nog één aspect aan mijn omschrijving van Comparative Management toe. Ik doe dat als een hommage aan mijn voorganger op deze plek, Hofstede en ook omdat ik overtuigd ben van het belang van deze toevoeging. Dat is aandacht voor het verschijnsel cultuur. Hofstede heeft dat omschreven als de collectieve geprogrammeerdheid van de geest (1984, 21). Ik heb zelf ooit aandacht gevraagd voor het institutionele karakter van cultuur en het begrip omschreven als een efficiënte standaardoplossing voor de problemen van het samenleven (Vroom, 1991, 4). Lammers kan ons bijeen brengen: de institutionele taakstelling van organisaties verschilt, en daardoor tevens de institutionele cultuur (1993: 321 en 326) en die heeft weer gevolgen voor de manier waarop mensen daarmee en met elkaar omgaan.

Er zijn verschillende grondproblemen te onderkennen in een samenleving. Verschillende soorten organisaties ontwikkelen zich ter oplossing van zulke problemen:

- het produceren van goederen en diensten (de economie);

- de zorg voor het geestelijk en lichamelijk welzijn (bijvoorbeeld het onderwijs en de gezondheidszorg);

- de zorg voor een interne en externe ordelijkheid (de staat, met behulp van bijvoorbeeld de politie en de krijgsmacht);

- en ga zo maar door.

In elk van deze instituties ontwikkelen zich door het gedrag en het nadenken van mensen eigen vormen van organiseren en leidinggeven, die met elkaar kunnen worden vergeleken en tegelijkertijd van elkaar te onderscheiden zijn. De betekenissen die mensen in zulke organisaties aan hun onderlinge verhoudingen hechten, zijn niet zonder meer gelijk. 
Even een voorbeeld tussendoor om duidelijk te maken wat ik bedoel. Denk aan medische specialisten in een ziekenhuis. Zij zien de kliniek en de daarbij behorende organisatie nogal eens als een privé-instrument dat zich vooral naar hun wensen moet schikken. $\mathrm{Zij}$ spreken daarom ook nogal eens van 'de bureaucratie' als het gaat om het niet direct patiëntgerichte deel van het ziekenhuis. En ze vinden bestuurders en directieleden vaak nogal hinderlijk op hun weg naar professionele autonomie. Die laatsten beoordelen vanuit hun eigen verantwoordelijkheid de positie van hun ziekenhuis op de markt voor gezondheidsvoorzieningen. $\mathrm{Zij}$ staan voor de kwaliteit van het geïntegreerde medisch handelen. Daarom maken ze bijvoorbeeld plannen om functioneringsgesprekken gaan voeren met deze specialisten om hun gedrag in deze richting om te buigen. De opvattingen over organisatie en management en over de plaats van de beslissingsmacht lopen dus nogal uiteen tussen bestuurders en specialisten. En alvorens er sprake kan zijn van enige vruchtbare dialoog, moeten die opvattingen eerst wat dichter bijeen worden gebracht. En dat geldt ook buiten ziekenhuizen.

Comparative Management houdt zich dus bezig met het vergelijkend onderzoek naar de verschillende, meer en minder vastliggende, manieren van denken en doen van mensen in organisaties, onder meer onderscheiden naar de dimensie tijd, institutie en geografische plaats en dan vooral gecentreerd op vraagstukken van vorm- en leidinggeven aan organisaties.

Ik vertel $u$ weer twee verhalen om nog wat meer kleur te geven aan het onderzoeksterrein van dit vak. Ik waarschuw u vast: ze zijn tamelijk extreem. Maar voordat ik daar aan begin, heb ik nog een klein beetje theorie nodig. Ik leen die weer bij Lammers. Hij heeft onlangs een handig onderscheid gemaakt tussen de verschillende partijen die bij een organisatie betrokken zijn (1993, 39 e.v.). Dat heeft hem waarschijnlijk wat moeite gekost omdat hij vroeger niet zo in de partijenbenadering geloofde $(1983,411)$. Hij noemt er vier: de topleiding, de loyale elite die de top helpt bij de uitvoering van het gewenste beleid, de gewone organisatiegenoten die belast zijn met de uitvoering van alledag en tenslotte de inheemse elite, een overigens tamelijk koloniale beschrijving van zich gaandeweg mobiliserende groepen, inheems in de zin dat zij niet aan de top van de organisatie bevinden en nog niet over daadwerkelijke macht beschikken. Na elk van de verhalen die ik u nu ga vertellen kom ik even op dat onderscheid terug. 
Ik ga eerst een heel eind terug in de geschiedenis. Op 2 januari 1492 gaf Mohammed Ben Ali, of in de Spaanse verbastering Boabdil, de vorst van het toenmalig Islamitische koninkrijk Granada, de sleutels van deze stad over aan de Spaanse katholieke koningen, Ferdinand en Isabel, die hun kamp hadden opgeslagen in Santa Fe, letterlijk vertaald "het heilige geloof" en de eerste plaats in de wereld met die veelzeggende naam. Granada was toen het laatste bolwerk van de Islam in West-Europa. Mensen van verschillende geloofstradities, Islamieten, Joden en Christenen leefden er tamelijk vreedzaam samen. De Islamieten bezaten weliswaar de staatsmacht, maar de beide andere partijen konden redelijk vrij hun gang gaan, onder de eenvoudige voorwaarde dat zij de hun opgelegde belastingen betaalden. Het was zelfs niet zeer opmerkelijk dat men van geloof wisselde als dat eens opportuun was, bijvoorbeeld in het geval van een voorgenomen huwelijk. De Spaanse koning Pedro liet enkele eeuwen eerder zijn paleis in Sevilla door Moorse architecten ontwerpen. En koning Alfons de Wijze richtte een school op in Toledo, waar Joden, Moren en Christenen onder meer Aristoteles vertaalden vanuit het Arabisch, iets waar we vandaag de dag nog steeds plezier van hebben. Dat zijn geen bewijzen van een verregaande verharding van standpunten. Het is dan ook niet vreemd dat bij de vijfhonderdjarige herdenking van het einde van de politieke presentie van de Islam in West-Europa er plakkaten in de stad Granada verschenen met de mededeling "en mil cuatro cientos noventa y dos perdímos todos", voor degenen die hun Spaans na de tachtigjarige oorlog niet meer zo hebben bijgehouden: "in 1492 hebben wij allen verloren".

De Moren kregen in eerste instantie het recht om in de stad te blijven wonen, om hun beroepen uit te oefenen en zeker ook om hun godsdienst te belijden. Het dominante karakter van de katholieke kerk in het Spanje van die dagen - denk ook aan de Inquisitie - leidde echter al snel tot de gedwongen bekering van deze bevolkingsgroep, een opmerkelijk voorbeeld van een vroeg cultuurveranderingsproces. Deze bekering verliep niet echt gemakkelijk omdat er onder meer te weinig was nagedacht over de hoeveelheid georganiseerde inspanning die zo'n proces nu eenmaal vereist. Na enige tijd liepen daarom de verhoudingen in Granada vast: de Moren, nu aangeduid als Moriscos, maar vaak ook als Nieuwe Christenen, moesten vertrekken naar het dal van de Alpujarras bezuiden de Sierra Nevada waar zij met - oude - Christenen moesten samenleven die hen moesten inleiden en voorgaan in de nieuwe opvattingen en gebruiken. Maar deze nieuwe Christenen bleven 
vasthouden aan enkele typische gewoontes: ze wasten zich regelmatig met fris water en ze deden geheimzinnige dingen binnenshuis op vrijdag. Zo ontstond er roddel, achterklap en toenemende onderlinge irritarie, uitmondend in beschietingen en brandstichting in elkaars kerken en moskeeën. In $1568 \mathrm{kwam}$ deze groep in opstand tegen het gezag van de koning van Spanje, juist zoals de bewoners van de Lage Landen bij de Noordzee. Dat levert een aardige coïncidentie op en daarmee ook de historische rechtvaardiging voor dit voorbeeld: Philips II, kleinzoon van de Brusselse bonvivant Philips de Schone en Johanna de Waanzinnige die weer de dochter was van de juist genoemde katholieke koningen, was tamelijk bezorgd over een mogelijke politiek-militaire driehoeksverhouding tussen de opstandige protestantse Hollanders, de lastige Islamitische Turken en de roerige Moriscos in Zuid-Spanje (3).

Het probleem vanuit het gezichtspunt van Comparative Management zit hem in de gedwongen bekering van de Moren tot het katholieke geloof en de bijbehorende zeden. Dat was een cultuurveranderingsproject van waarlijk enige omvang, waarbij zoals gezegd nauwelijks was nagedacht over fasering, ondersteunende activiteiten, communicatieprocessen en voorbeeldgedrag. Het ging om honderdduizenden mensen op verschillende plaatsen in het toenmalige Spanje en om een tijdsperiode die de hele zestiende eeuw besloeg. De opmaat was tamelijk eenvoudig: iedereen dopen. Maar over geschikte lesstof, over het tijdig en uitgebreid beschikbaar hebben van opvoedingsprogramma's en de daarvoor benodigde omscholingsfunctionarissen, over controle op voortgang en effectiviteit, over dat soort zaken had men volstrekt niet nagedacht. De top had zich in termen van Lammers niet voorzien van een loyale elite, waardoor de gewone organisatiegenoten als het ware in de lucht bleven hangen, en waardoor het ontstaan van tegendraadse inheemse elites werd bevorderd. Het einde van dit proces is daarom vrijwel voorspelbaar: toenemende intolerantie bij de top en tenslotte verdrijving van de andersdenkenden, een vorm van etnische zuivering dus die wij tegenwoordig ook elders waarnemen.

Wat valt er te leren van dit gigantische cultuurveranderingsproject avant la lettre? In de eerste plaats: als zo'n verandering afgedwongen wordt vanuit de overtuiging dat degenen die de gewenste cultuur en ook de macht bezitten, daarom alle soorten van gelijk hebben en zich dus niet hoeven te bemoeien met de vraag of en hoe de te veranderen groep naar een nieuwe situatie over moet gaan, dan gaat het gegaran- 
deerd fout. Dwang zonder innerlijke overtuiging dat men ook echt anders moet, dwang zonder inzicht dus met andere woorden, werkt niet echt. Mensen willen immers alleen veranderen als zijzelf de zin ervan inzien: meestal betekent zoiets dat zij mee kunnen bepalen hoe zulke veranderingen eruit moeten gaan zien. Men zou heden ten dage kunnen denken aan de omvorming van Zuid-Afrika. Mandela heeft daar terecht gepleit voor voorzichtigheid en fasering en tevens voor toekomstgerichtheid. Helderheid over het verleden is gewenst, want men moet niet vergeten. Vergeven is wel aan de orde omdat uiteindelijk iedereen in de strijd wel eens vuile handen heeft gemaakt. Vergeven gaat des te gemakkelijker als het inzicht bij alle betrokkenen aanwezig is dat men vooruit moet, liever nog wellicht alleen vooruit kàn als men het samen doet.

$\mathrm{Zijn}$ de veranderingsprocessen in een grote onderneming in het Zuiden des lands zo anders waar men uit alle macht probeert een klantgerichte cultuur ingang te doen vinden, maar waar een zogenaamde rubberen laag in het midden van de organisatie elk initiatief lijkt te dempen? Gaat het zo anders in de Koninklijke Landmacht waar men na een jarenlange procedurecultuur nu resultaatgericht probeert te werken en er dan gevoelige brieven en lijsten ergens op een bureau blijven liggen? Ik denk het niet en volgens mij kunnen wij veel leren van de ervaringen die vroeger en elders op soortgelijke terreinen zijn opgedaan. Dat is dus een belangrijke inhoudelijke rechtvaardiging voor de beoefening van het vak van Comparative Management, ook en juist in zijn historische component.

Ik vertel $u$ nog een verhaal en ik ben mij bewust dat $u$ even moet wennen aan mijn perspectief. $\mathrm{Er}$ is in 1993 een interessante, maar tegelijk stuitende studie verschenen over concentratiekampen in de Nazitijd (Sofsky, 1993). Sofsky beschrijft en analyseert de concentratiekampen als organisaties met een eigen structuur, cultuur en besturingswijze. Het beeld wat daaruit oprijst is allesbehalve opwekkend. De SS had een redelijk succesvolle (woorden schieten hier in emotionele nuancering tekort) organisatie opgebouwd die men het beste kan beschrijven aan de hand van concentrische kringen. In het midden de gevangenen, daaromheen en uit deze gevangenen gekozen de Kapo's en blokoudsten, daaromheen weer een ring van allerlei eigenaardige lieden (zoals uit de gevangenis ontslagen misdadigers, jongelui die afgekeurd waren voor de dienst, volksduitsers uit de bezette gebieden en gewone colla- 
borateurs) en tenslotte een ring van zogenaamd 'normale' SS-ers. Het belangrijkste beloningsmechanisme was van buiten naar binnen gericht: het - voorlopig - afzien van het gebruik van vergaand fysiek geweld tegen personen. In zo'n extreme situatie versterkt dat kennelijk wat we hier - heel klinisch - cultuur noemen. De partijen van Lammers zijn hier goed herkenbaar. De topleiding bepaalt de koers en maakt geen vuile handen. $\mathrm{Z}_{\mathrm{ij}}$ weet kennelijk zelfs naar buiten toe veel toe te dekken. Er zijn loyale elites gevormd, die het werk doen en er is een tamelijk simpel, doch doeltreffend middel om het ontstaan van inheemse elites tegen te gaan.

We kennen allen de uitkomsten: welke vreselijke dingen er gebeurd zijn in deze kampen. Toch is het de moeite waard om ernstig naar te kijken. Het is een extreem geval, en op de details ervan wil ik nu niet ingaan. Maar juist extreme ervaringen leren ons veel over de typische manier waarop mensen hun onderlinge verhoudingen vorm kunnen geven. We hoeven die ervaringen niet experimenteel en gecontroleerd op te wekken: mensen zijn kennelijk in staat dat uit zichzelf te doen. We moeten er zeker wel van leren, ook door zulke zaken goed te analyseren.

Het voorbeeld dat ik net gaf van een concentratiekamp als leerzame organisatie is juist vanwege de ethische aspecten nogal schokkend. Ik ben me daar terdege van bewust. Het gaat me echter niet alleen om de inhoud van dat voorbeeld, maar vooral om de manier waarop we ernaar kijken. Het is dus kennelijk mogelijk om in organisaties structurele en bestuurlijke arrangementen op te zetten die nogal - laat ik het maar eenvoudig zo zeggen - ongewenste waarden en normen in stand kunnen houden. Er zijn dus blijkbaar grenzen aan het organiseren. Wij kunnen dus niet volstaan met de pure feiten te presenteren en daarop klinische analyses te plegen; we moeten ook nagaan wat de ethische implicaties zijn van onze bevindingen. Aan het einde van deze oratie kom ik ook daar nog op terug.

Ik sluit nu het eerste deel van mijn betoog af, waarin ik u heb meegenomen in een tour de horizon langs verschijnselen die ik voor het vak Comparative Management interessant vind. $\mathrm{Nu}$ ga ik over naar het tweede deel van mijn verhaal en bekijk met $u$ de methode waarop dit vak is bedreven en waarop het naar mijn mening bedreven moet worden. 


\section{METHODOLOGISCHE OVERPEINZINGEN}

Ik wil daarover niet te moeilijk doen en begin dus met iets heel simpels: u zit in deze zaal, de oude kapel van het klooster van de Jezuïeten en nu de aula van de Rijksuniversiteit Limburg. Bedenkt u zich even hoe u naar deze inaugurele rede kunt kijken. De rituelen die nu plaats vinden, hebben verschillende betekenissen, voor de Rector als voorzitter, voor de pedel als hoeder van de academische riten, voor $\mathrm{u}$ als gehoor, voor mij als spreker, voor de mensen van de receptie straks en voor de horeca-uitspanningen in Maastricht waar $\mathrm{u}$ wellicht vanavond heen gaat. Iedereen bekijkt zoiets vanuit zijn eigen perspectief, kennis, ervaring en opvattingen. We hebben ieder op onze eigen wijze deel aan deze gebeurtenis, en daarom blijven we erbij, al zijn er allicht een paar onder $u$ die op deze vrijdagavond verlangend uitzien naar de receptie.

In de monswetenschappen is het niet veel anders. Ook daar geldt dat mensen vanuit hun eigen perspectief, kennis, ervaring en opvattingen naar de te onderzoeken verschijnselen kijken. En die beperkingen gelden ook nog eens voor die verschijnselen zelf, want die worden op hun beurt ook weer door mensen gemaakt. Een caleidoscoop dus van in elkaar grijpende betekenisstructuren. Hoe is daar nu enige helderheid in te brengen?

Dat is een oude vraag, die in deze eeuw annleiding is geweest tot verschillende debatten over de methode van de sociale wetenschappen. Weest u gerust, ik haal die nu niet terug. Maar ik wil toch op een paar zaken wijzen. Die hebben te maken met het wereldbeeld van onderzoekers, met de objectiverende methode die door velen wordt aangeprezen en tenslotte met wat $\mathrm{ik}$ in tegenstelling daartoe de abstraherende methode zou willen noemen.

Eerst dus het wereldbeeld van de onderzoekers. Roe, Schalk en Zijlstra (1995: 209) pleitten onlangs voor het loslaten van een universalistisch wereldbeeld in de sociale wetenschappen, dat gebaseerd lijkt te zijn op aannames van constantie en generaliteit. Dat klinkt ingewikkelder dan het is. Mensen, en vooral dus wetenschapsbeoefenaren, hebben de neiging te zoeken naar verklaringen, die onathankelijk van bijvoorbeeld tijd en plaats geldig zijn. Dat scheelt werk, want dan kan men op grond van één verzameling getoetste uitspraken zeggen hoe de zaken in elkaar zitten, wellicht zelfs ook wat men doen moet om een gewenste toestand te bereiken. Nu heb ik u net verteld dat in dit vakgebied de zaken naar tijd, institutie en plek in de wereld nogal kunnen verschil- 
len. Dan is het vasthouden aan zo'n universalistisch wereldbeeld niet erg vruchtbaar. De onderzochte wereld verandert bovendien sneller dan men zijn bevindingen kan verwerken en op papier zetten. En juist daarom is het wellicht verstandiger het veld anders te benaderen. Waarom niet geprobeerd veranderlijkheid en verscheidenheid van situaties als uitgangspunt te nemen? Waarom niet veel meer aandacht besteed aan descriptief en begripsvormend onderzoek, aan vergelijkende toetsing en dan pas pogingen tot enige hiërarchische ordening? Dat lijkt mij een vruchtbare gedachtengang, die goed spoort met hetgeen ik hierboven heb beweerd en die misschien nog één stap verder moet worden gebracht. Het onderzoek op het terrein van Comparative Management moet juist worden gekenmerkt door pogingen de veelheid en variëteit van verschijnselen in kaart te brengen. Om elkaar te begrijpen is het wel handig om zoveel mogelijk gemeenschappelijke begrippen te gebruiken. Kennisnemen van hetgeen op dit terrein in wetenschappelijke zin al is gedaan is daarom een noodzakelijke voorwaarde. Even noodzakelijk en wellicht beter is een onuitblusbare belangstelling voor wat men de biodiversiteit zou kunnen noemen van praktische oplossingen voor de veelsoortige en veranderlijke problemen die leidinggeven en vormgeven aan organisaties nu eenmaal met zich mee brengen. Dat is ecn wereldbeeld gebaseerd op - chique gezegd - variantie en diversiteit.

Dan de objectiverende methode. Ik versta daaronder de gedachte dat men door wetenschappelijk onderzoek de feiten zelf zou kunnen laten spreken, zonder dat de onderzoeker of de onderzochte mensen daarin een rol spelen. Het zal u niet verbazen als ik zeg dat ik bezwaar heb tegen die methode als die als enig juiste, of wetenschappelijk verantwoorde wordt voorgestaan. Ik geef $u$ een voorbeeld van wat ik daarmee bedoel. Ik kwam het tegen in een boek van Keuning en anderen (Keuning e.a.,1993) over verplatting van organisaties. $\mathrm{Zij}$ hebben onderzoek gedaan naar het verband tussen de steilte van de organisatiestructuur en de effectiviteit van een organisatie. Steilte als begrip slaat op het aantal hiërarchische lagen in de organisatie en de gemiddelde span of control. Spijtig genoeg kunnen de onderzoekers uit de gegevens niet de conclusie trekken dat een platte structuur per definitie effectiever is dan een steile. En eerlijk gezegd, dat verbaast me niets.

De begrippen die zij gebruiken zijn gebaseerd op een objectiverende manier van benaderen van het organisatieverschijnsel. Effectiviteit en 
steilte zijn beschrijvingen van objectieve kenmerken van organisaties, kenmerken dus die op het eerste gezicht niets te maken hebben met de mening van mensen in zo'n organisatie. Nadat zij hun oorspronkelijke veronderstellingen hebben moeten verwerpen, en die eerlijkheid siert hen, presenteren zij met enige terughoudendheid hun deelbevindingen. Die zijn echter juist veelzeggend, want die gaan namelijk wel over hoe mensen denken en doen in organisaties:

- tevredenheid van organisatieleden in plattere structuren is hoger; dat geldt vooral voor lager management en 'grenswerkers'. De tevredenheid van het topmanagement stijgt echter bij steile structuren;

- platte structuren zijn effectiever in turbulente situaties, steile juist meer in stabiele;

- effectieve besluitvorming vergt een zekere mate van hiërarchie, vooral vanwege de herevaluatie van voorgenomen beslissingen die op de verschillende niveaus plaatsvindt.

Vindt $\mathrm{u}$ het vreemd dat lagere organisatieleden meer voldoening ondervinden van hun werk in een plattere structuur? $\mathrm{Zij}$ beoordelen de grotere ruimte die zij krijgen positief. En is het verbazingwekkend dat topmanagement zich lekkerder voelt bij een steile structuur? Dat vergroot namelijk in het algemeen de macht van de top om dingen gedaan te krijgen, zonder overigens zelf daar de directe gevolgen van te ondervinden. In een platte structuur immers gaan opdrachten of mededelingen vanuit de top namelijk direct de oren in van degenen voor wie ze bestemd zijn en dat kan best wel eens tot tegenspraak leiden. Als de organisatie zich in een turbulent veld bevindt (en welke niet tegenwoordig?) kan men zo creatieve en flexibele oplossingen vinden, maar het is tegelijkertijd hinderlijk voor de mannen en vrouwen aan de top die worden tegengesproken. En ook de bevinding van de herevaluatie van besluiten is interessant. Het gaat erom dat verschillende mensen kennelijk nieuwe overwegingen, argumenten, en dus als het ware lagen toevoegen aan voorgenomen beslissingen. Het is dus de moeite waard om te zoeken naar de betekenissen die deze functionarissen aan het oorspronkelijk voorstel toevoegen en de reden waarom zij dat doen. Een tamelijk objectief-mechanische aanpak van de dingen gaat daaraan voorbij: zorg voor meer niveaus in de beoordeling van de besluitvorming en organisatorische besluiten worden vanzelf beter van kwaliteit. In grote organisaties als bijvoorbeeld de universiteit en de krijgsmacht weten we dat zoiets wel eens anders verloopt. 
Nog een voorbeeld waarin ook mijn eerste bezwaar tegen het universalistisch wereldbeeld terugkomt: het onderzoek van Hofstede (1983) naar cultuur. In zijn fameuze Culture's Consequences doet hij verslag van een empirisch onderzoek onder een grote groep medewerkers van een bekend informatica-concern. Op grond van zijn bevindingen schetst hij een organisatiecultuur die uit een vijftal dimensies bestaat, dimensies die op verschillende manieren in verschillende landen met elkaar samenhangen. Hij is daarmee een van de eersten geweest die uitdrukkelijk aandacht heeft gevraagd voor de verschillen in cultuur tussen verschillende landen en dat siert hem. Het probleem zit hem echter in de Westerse bril die Hofstede hanteert en die door zijn methode als het ware achter de horizon verdwijnt. Hij stelt namelijk zijn vragen vanuit een eigen, eveneens cultuurbepaalde organisatie-ervaring en constateert dat mensen in meer dan 40 landen, maar allen binnen dezelfde onderneming, daar antwoord op weten te geven. Hij thematiseert niet waarom en hoe zij antwoord geven op zijn vragen, maar gebruikt de antwoorden om cen universalistisch cultuurmodel te construeren, waarin per land de sterkteverhouding tussen de dimensies kan verschillen. Dat leidt tot een mijns inziens gevaarlijke objectivering, waarin de zingeving van mensen ontdaan wordt van zijn historische en institutionele dynamiek. Ik sluit me liever aan bij Whitley (1992) die vaststelt dat landen, organisaties en mensen met nogal wat succes verschillende strategieën kunnen volgen op het stuk van respectievelijk modernisering, industrialisering en ontwikkeling (4). Overigens moet Hofstede worden toegegeven dat hij naderhand in 1991 op zijn standpunt terugkomt. Hij erkent dan dat zijn benaderingswijze het gevaar van ethnocentrisme inhoudt.

Ik zou dus vooral willen vragen naar wat de mensen zelf bezighoudt in organisaties. Dat is dan hun interpretatie van de manier waarop zij samen vorm geven aan hun onderlinge verhoudingen. De overeenkomsten en verschillen daarin zouden volgens mij met de eenvoudige methode van de abstractie goed in kaart kunnen worden gebracht. Dat verloopt als volgt. We stellen vast dat we willen weten hoe en welke betekenis mensen geven aan hun bijdrage aan het verloop van het organisatorisch gebeuren en de leiding daarvan. We verzamelen zoveel mogelijk gevarieerde ervaringen, in de tijd gezien, in verschillende instituties en in verschillende landen. Van die ervaringen trekken we als het ware het bijzondere af zodat we het meer algemene overhouden. Max Weber heeft dat de ideaaltypische methode genoemd, waarin het 
gaat om het achterhalen van de zingeving die mensen in hun gedrag leggen. En ik voel me thuis bij zijn uitspraak dat de vooruitgang in de wetenschap bepaald wordt door verschuivingen in de praktische problemen die een samenleving ervaart (Weber, 1968, 58). Daarom acht ik een benadering van het terrein van Comparative Management vooral vruchtbaar als er rekening gehouden wordt met variantie en diversiteit, met de betekenis die mensen zelf aan hun gedrag geven en als zij vorm krijgt in steeds verschuivende ideaaltypische constructies.

Dat is voor dit moment genoeg over de methodologie. Ik ga over naar het derde deel: wat hebben we aan al deze inzichten. 


\section{BRUIKBAARHEID}

Zoals ik in het begin van mijn oratie al heb gezegd wil ik nu twè pleidooien houden: een voor het instandhouden van de verscheidenheid van theorie over management en organisatie, en een voor tact en tolerantie in de omgang met mensen die geloven in hun eigen organisatorische oplossingen. Voor het gemak vat ik tenslotte nog enkele dingen samen.

Waarom verscheidenheid van theorie over management en organisatie? Hoe zorgelijk zou het niet zijn als ons denken over de veelheid van verschillende soorten organisatie en management gaandeweg zou verschrompelen tot enkele standaardmethodes en -resultaten?. Dat is immers een van de onbedoelde gevolgen van academische opleidingen: studenten worden geconfronteerd met de op dat moment gangbare literatuur en denken dat de wereld echt zo in elkaar zit. Ze komen naderhand in de echte werkelijkheid met de gedachte dat in hun boeken alle oplossingen voor alle problemen te vinden zouden zijn. En er zijn er die nog verder gaan. Zij prijzen de dynamiek van de mondiale competitie en stellen dat de verschillende vormen van organisatie en management daardoor steeds meer op elkaar zullen gaan lijken. Steeds meer eenvormigheid dus, vandaar de titel van deze oratie, maar wel met een vraagteken. Kijken we naar de biologie: daar verdedigen verstandige mensen immers ook het instandhouden van de biodiversiteit van genetisch materiaal met kracht. De metafoor van een genenbank van gedachten over organisatie en management lijkt me wel aardig. Zo'n bank is voor iedereen vrij toegankelijk vooral om er te leren en op grond daarvan vernieuwing te realiseren. Ik geef vast een eerste bijdrage aan zo'n genenbank.

In de NRC van 6 september j.1. schreef Kuiken, de hoofdredacteur van het mij verder niet bekende Journal of Engineering Mathematics dat de Chinezen tegenwoordig in hun onderwijs grote nadruk leggen op wiskunde en dat zij op de Internationale Wiskundeolympiade vaak de eerste prijs behalen. Het wiskundig denken ligt ten grondslag aan de moderne techniek en economie. Het is daarom volgens hem te verwachten dat in de volgende eeuw een geweldige kennisgolf vanuit dat land op ons afkomt. Ik citeer hem met instemming: "Die golf zal mensen die blijven geloven in de superioriteit van onze aanpak, geheel verrassen. Anderen zullen zeggen dat het zo'n vaart niet zal lopen. Die zijn misschien te jong om zich te herinneren wat de heer Verolme in 
de zestiger jaren zei toen het thans niet meer bestaande scheepsbouwbedrijf dat hij leidde met enorme concurrentie vanuit Japan werd geconfronteerd: "Maar die lui werken voor een hand rijst. Zo kan ik het ook". Dat hij werd verslagen door superieure produktie-, organisatieen onderzoektechnieken merkte hij pas toen het te laat was." Dat is precies de terughoudendheid die ik bedoel. Wellicht wordt vanavond ergens ter wereld cen oplossing bedacht en/of gerealiseerd voor een probleem dat wij wellicht helemaal nog niet als zodanig ervaren. Het afbreken van de genenbank door eenzijdig de nadruk te leggen op universele en daardoor tot het monistische neigende theorie is daarom nogal gevaarlijk.

En dan mijn pleidooi voor tact en tolerantie. Dat is gebaseerd op twee overwegingen. De eerste daarvan heeft te maken met mijn opvattingen over methodologie. Ik heb u geprobeerd duidelijk te maken dat ik weinig voel voor een objectiverende en daarmee als het ware een uiteindelijke waarheid vastleggende benaderingswijze. Ik heb een keuze gemaakt voor een constructivistische anpak waarin steeds opnieuw als het ware de waarheid geschapen wordt en geen uitspraak gedaan wordt over de uiteindelijke morele waarde van een bepaalde cultuur, de manier van denken en doen van mensen in hun alledaagse dynamische wereld. Die uitspraak kan namelijk niet worden gedaan omdat alleen de voortdurende dialoog tussen mensen het fundament kan vormen voor de meningsvorming omtrent het rechtvaardig handelen. En dat is meteen mijn tweede overweging. Said heeft dat ooit goed gezegd (Said, 1993): intellectuelen hebben niet alleen de plicht om verheldering te bieden in complexe kennisgebieden, maar tevens ook om bij te dragen aan maatschappelijke tolerantie. Dat is precies de functie van de universiteit. Het gaat uiteindelijk om het fatsoen dat de onderzoeker, intellectueel, wetenschapsbeoefenaar, en dan ook de practicus die zich laat voorstaan op het gebruik van zijn academisch geschoold gezonde boerenverstand, moet betrachten tegenover degenen die kennelijk een andere vorm van denken en doen op het terrein van management en organisatie hebben gevonden dan hijzelf heeft. Het kan niet zo zijn dat wij in dit kleine gedeelte in tijd en plaats van de wereld de uiteindelijke of zelfs maar de voorlopig beste vorm van management en organisatie zouden hebben gevonden. Daarom past ons bescheidenheid en respect en tact en tolerantie. 
Het gevolg van dit standpunt is dat men de comparatieve bedrijfskunde theoretisch en praktisch slechts kan bedrijven vanuit een grote tolerantie voor verschillende opvattingen over management en organisatie. Het werkterrein van dit vak beslaat de vergelijking tussen wat door ons voor normaal wordt gehouden en het vreemde, dat gebaseerd is op andere persoonlijkheidskarakteristieken, andere organisatorische gewoontes en andere institutionele inbeddingen. Wij moeten ons hoeden voor het gevaar van veroordeling van het onbekende, zoals Kundera opmerkt, omdat het niet zou passen in een bekend systeem $(1994,152)$. "Maar wie denkt, dient zich niet in te spannen om anderen van zijn waarheid te overtuigen; zo zou hij de weg van een systeem bewandelen; de beklagenswaardige weg van de man-met-vaste-overtuigingen; politici noemen zich graag zo; maar wat is een overtuiging? Dat is een denken dat tot stilstand is gekomen, verstard is, en de man met vaste overtuigingen is een geborneerde man; het experimentele denken wenst niet te overtuigen maar te inspireren; te inspireren tot een ander denken; het denken in beweging te zetten...."

De lerende organisatie (zie bijv. Senge, 1990, 1994; Van den Broeck 1994) vormt het snijpunt van twee bewegingen: de ene is gericht op het verkrijgen van data/kennis over objectgeoriënteerde zaken, de andere op het verzamelen van informatie over meer subjectgeoriënteerde zaken. Wat betekent dat? Objectgeoriënteerd leren betekent niets anders dan informatie verzamelen, ordenen en toegankelijk maken over verschijnselen in de buitenwereld, dus buiten onszelf. Iedere leidinggevende doet dat omdat hij moet weten wat er buiten hem gebeurt, zowel in zijn organisatie als in de wereld daar weer buiten. Hij verwerkt die informatie tot handelingsplannen en stelt die bij waar het nodig is. Subjectgeoriënteerd leren heeft te maken met het feit dat men zelf ook in dat leerproces staat en men dus steeds ook het eigen denkraam moet thematiseren. Is in het objectgeoriënteerde leren vooral het directe leren aan de orde, in het subjectgeoriënteerde leren gaat het om hoe iemand aan het leren is; anderen hebben dat ook wel single en double loop learning genoemd. Objectgeoriënteerd leren leidt tot institutievorming: zo doen wij het hier altijd, zo benaderen wij de werkelijkheid, dat zijn onze manieren. Subjectgeoriënteerd leren leidt tot flexibiliteit en vernieuwing omdat men zo zijn perspectief kan veranderen. De combinatie van beide leervormen kan ons verder helpen. 
We hebben al veel bereikt. Op allerlei institutionele terreinen kunnen we redelijk efficiënt goederen en diensten produceren. Aan klanten, cliënten, studenten enz. bieden we interessante zaken aan. De technologische vooruitgang is indrukwekkend. De financiële en sociale onderbouwing van onze organisaties is in vergelijking met het verleden veel sterker geworden. Die ontwikkelingen gaan ongetwijfeld verder en zijn de moeite van het bestuderen waard.

Maar in de toekomst liggen ook spanningen op ons te wachten, waarbij we belangrijke keuzes zullen moeten maken. Denk aan de spanning tussen rendementsverhoging op kapitaal en aan de andere kant het rendement van het organiseren voor mensen en de samenleving waarin zij wonen; topwinsten bij de bedrijven en afnemende werkgelegenheid; toenemende mobiliteit en flexibiliteit en aan de andere kant de zorg voor het leefmilieu; de toenemende mondiale vervlechting op minstens het economische terrein en aan de andere kant het belang van lokale sociale netwerken en daarmee ook geborgenheid van mensen; de omvorming van organisatorische verbanden tot plekken waar het weer leuk en uitdagend is om te werken en aan de andere kant de noodzaak tot enige centrale sturing en afstemming van maatschappelijke processen waarbij niet iedereen altijd zijn zin zal krijgen.

Juist daarin ligt de uitdaging van het beoefenen van het vak Comparative Management. We moeten wetenschappelijke theorie zien als het antwoord op verschuivende praktische problemen. Max Weber heeft daar al op gewezen toen hij schreef over de vooruitgang in de wetenschap. Zoals in organisaties afspraken tot stand komen omdat men bepaalde problemen ervaart in het samenwerken en die voor de nabije toekomst wil oplossen, zo ook geldt dat voor de wetenschap en dus ook voor de theorie van organisatie en management. En alleen door tactisch en tolerant, maar tegelijk ook kritisch èn innovatief te willen blijven leren, hebben we kans betere oplossingen te realiseren voor de problemen van het organiseren, leidinggeven en samenleven. 


\section{TENSLOTTE}

Aan het einde van mijn oratie wil ik mijn dank betuigen aan het College van Bestuur van deze universiteit voor mijn benoeming.

Vervolgens mijn academische vrienden uit de Katholieke Universiteit Brabant in Tilburg, de Koninklijke Militaire Academie in Breda en elders uit het land: de veelsoortigheid van ervaringen die ik in de afgelopen bijna dertig jaar met $u$ heb gedeeld, stellen mij in staat de mij gegeven opdracht tot vergeliiking daadwerkelijk waar te maken. Het is ook die veelsoortigheid die mij ertoe heeft gebracht een pleidooi te houden voor verscheidenheid van theorievorming over organisatie en management om te voorkomen dat het denken daarover tot eenzijdigheid verschraalt.

Waarde Hofstede: ik heb u leren kennen bij een gloedvol betoog over uw cultuurstudies tijdens een EGOS-conferentie in Denemarken in de jaren zeventig. Ik heb wat kritiek geformuleerd op uw methodes. Ik moet daar meteen bij zeggen dat ik mede door uw boek uit 1991, waarin u erkent dat uw eerdere benadering tamelijk gebonden was aan de westerse cultuur, ben angezet tot mijn pleidooi voor tact en tolerantie in de omgang met mensen die op een andere manier denken en doen binnen en tussen organisaties.

Dames en heren collegae van Wagenaar, Hoes en Associés: ik dank u voor de mij geboden gelegenheid om dit hoogleraarschap te vervullen naast de rijke en overigens vaak nogal snelle ervaringen van het organisatie-adviesvak. Ik zie mijn activiteiten op dat vlak als de kaas op het brood of wellicht ook als de kroon op mijn werk van de afgelopen dertig jaar.

Dames en heren van de vakgroep Internationale Bedrijfskunde: ik heb velen van $u$ al leren kennen en ben gerust gesteld door de plezierige en wetenschappelijke sfeer die u kenmerkt. Een deeltijdse hoogleraar blijft altijd een beetje vreemde eend in de bijt, en deze heeft ook de neiging nogal eens uit te vliegen. Ik ben er zeker van dat wij goede en vruchtbare contacten kunnen blijven onderhouden.

Dames en heren studenten: mijn motto in het begin van deze oratie was: je komt nog eens ergens en je hoort nog eens wat. Als ik u dezelfde nieuwsgierigheid kan bijbrengen die mij tot de beoefening van deze 
tak van wetenschap heeft gebracht ben ik al heel tevreden. Sommigen uwer hebben dat al overgenomen: ik kom ze bijvoorbeeld tegen op mijn reizen naar Zuid-Afrika.

Marphy en Meike: datzelfde motto leidt er ook toe dat ik veel van huis weg ben voor kortere of langere periodes. Ik dank jullie voor het soms zuchtend opgebrachte begrip. Overigens weet ik zeker dat jullie ook ondernemend en reislustig zijn. Daarom moeten we elkaar blijven zoeken om elkaar zo wijd de wereld strekt te ontmoeten.

Ik herdenk tenslotte met weemoed mijn zoon Harm die in 1989 overleden is.

Ik heb gezegd. 


\section{NOTEN}

1. Max Weber heeft ooit gezegd (Politik als Beruf, Wissenschaft als Beruf) dat een intellectueel onderscheid dient te kunnen maken tussen de wetenschappelijke en de toegepaste benadering van maatschappelijke verschijnselen. In het eerste gaat het om kennis, in het tweede om waarden. Het zijn volgens hem twee gescheiden domeinen. Ik zou daar iets voorzichtiger tegen aan willen kijken. Het gaat ook om de vraag hoe men zijn vragen stelt en welke gevolgen men aan de antwoorden, maar ook aan het stellen van zulke vragen verbindt. De gedachte dat het gebruik van wetenschappelijke taal op zich een koloniserende invloed heeft, waarmee de rijkdom van de diversiteit van menselijk denken en doen wordt ingeperkt, maant ons tot voorzichtigheid. In de wijze waarop men vergelijkingen maakt tussen stelsels van management en organisatie moet het respect doorklinken voor hetgeen die anderen denken en doen. Het blijft het eeuwige dilemma van de wetenschap: zodra je iets hebt vastgesteld, leg je het daarmee ook vast en ontgaat een derde wellicht het fundamentele van het vaststellingsproces zelf. Het gaat dus kennelijk meer om het spel dan de knikkers. En tegelijkertijd vragen velen naar die knikkers, al was het alleen maar in de voortgaande rationaliseringsdrift van de universiteit, waarin meetbaarheid van de output een soort godsbewijs is geworden.

$\mathrm{Er}$ is bovendien verschil tussen de analytische socioloog en de prescriptieve organisatiekundige, die zich in een bedrijfskundige opleiding heeft genesteld. Deze twee kanten van de medaille zijn academisch te onderscheiden, en daarom in dit verband gepast. Maar men moet zich er wel bewust van zijn dat in de werkelijkheid buiten de universitaire studeerkamer deze zaken altijd dooreen lopen en dat het zelfs goed is te weten dat het onderscheid wel, maar de scheiding niet gemaakt kan worden, al was het alleen maar om zich er buitengewoon van bewust te zijn dat maatregelen / activiteiten / beslissingen niet alleen voortkomen uit een rationele inzet van middelen, maar altijd ook te doen hebben of gevolgen hebben voor mensen, die dus terecht vragen kunnen en mogen stellen bij de ethische component van het organiseren.

2. Ik ontmoette laatst een naaste medewerker van Mintzberg die mij vertelde hoe ze de beroemde vijfdeling van organisatietypen hadden bedacht. Ze hadden heel wat bedrijven en instellingen onderzocht, direct en via studenten, en wilden die informatie wat gaan ordenen. 
De beste oplossing leek een fietsvacantie in Frankrijk. Zuur in de benen en wijn in het hoofd waren kennelijk voorwaarden om de flits te krijgen dat het coördinatiemechanisme de aardigste basis zou vormen. En daarna worden studenten wereldwijd overtuigd van het feit dat organisaties nu eenmaal zo in elkaar zitten. Ik heb waardering voor het werk van Mintzberg en de zijnen, maar word wat onrustig van de gedachte dat iedereen onder het juk daarvan doormoet. Dezelfde onrust bekruipt me bij allerlei management- en advieshypes als 'total quality management' en 'business process reengineering'. Het gaat er toch om steeds goed te blijven waarnemen en voorzichtig te zijn met oordelen.

3. Ik ben geen historicus, maar wel gefrappeerd door het feit van wat men organisatorische beschaving (zie ook Vroom, 1991) zou kunnen noemen. Daarin is zeker geen rechtlijnige vooruitgang in te onderkennen, zoals tot op de dag van vandaag blijkt. Wie overigens meer wil weten van de typische geschiedenis van de Morisco's, kan te raden gaan bij de dit jaar overleden Spaanse hoogleraar Julio Caro Baroja, Los Moriscos del Reino de Granada, Madrid, 1991, en bij G.W. Drost, De Moriscos in de publicaties van Staat en Kerk (14921609), 1984. Ook de historicus C.V. Lafeber wijdt in De Nederlandse Opstand, 1555-1588, Goirle, 1994 enige passages aan de samenhang der gebeurtenissen in de Nederlanden en Spanje.

4. Kerr verdedigde reeds in 1960 de these van de convergentie van samenlevingen. Omdat er slechts één logica van industrialisering zou bestaan, zouden gaandeweg alle landen zich aansluiten bij het model van de hoogontwikkelde samenleving (en denk dan vooral aan de Verenigde Staten, niet alleen in economisch maar ook in sociaal opzicht. Naderhand (1983) heeft hij deze these enigszins verzacht: er bestaat minstens een spanning tussen de eisen die industrialisering stelt aan landen die nog niet zover zijn en de bestaande economische en sociale structuren. De noodzaak tot modernisering is een gevolg van de toenemende intensiteit van de internationale concurrentie, gemeenschappelijke menselijke behoeften aan voedsel, onderdak, vrijheid van verplaatsing, communicatie en meningsuiting, en ook van de gedachte dat gemeenschappelijk ervaren problemen noodzakelijk tot gedeelde oplossingen moeten leiden (zie ook Child, 1994). 
Zo'n gedachtengang is in strijd met het moderne denken over chaos en flexibiliteit, waardoor juist vanuit vrijwel gelijke beginsituaties zeer verschillende voorlopige eindstadia kunnen worden bereikt.

De convergentiethese wordt ook aangevallen door Clegg (1990). Hij wijst er terecht op dat er wereldwijd tamelijk verschillende vormen voorkomen van succesvol organiseren, zowel in de sector van de overheid als in die van het bedrijfsleven. Hij beargumenteert dat door te wijzen op de samenhang tussen concrete maatschappelijke institutionaliseringsprocessen en de vormgeving aan economische en statelijke organisaties. Als er geen samenhang tussen beide processen zou bestaan, dan zou het pas echt vreemd zijn. Zulke zaken versterken de als normaal geaccepteerde gang van zaken in samenlevingen èn organisaties. Het is juist de moeite waard om je af te vragen hoe en in welke mate gewoontes van denken en doen tot stand komen en in stand worden gehouden. Daarnaast blijft het de moeite waard om je af te vragen hoe machtsvormingsprocessen en machtsspelen verlopen omdat die natuurlijk ook veel met institutievorming rond belangengroepen en dergelijke te maken hebben. 


\section{LITERATUURVER WIJZINGEN}

Andersen, H.Chr., Sprookjes en vertellingen, Utrecht, 1952.

Broeck, H. van den, Lerend Management, Tielt, 1994.

Caro Baroja, J., Los Moriscos del Reino de Granada, Madrid, 1991. Child, J.S., Management in China during the Age of Reform, Cambridge, 1994.

Clegg. S.R., Organization Theory and Class Analysis, Berlin, 1990.

Drost, G.W., De Moriscos in de publicaties van Staat en Kerk (1492-1609), 1984.

Hofstede, G., Culture's Consequences, Beverly Hills, 1984.

Hofstede, G., Cultures and Organizations: Software of the Mind, London, 1991

Homerus, Odyssee, in de vertaling van A.W. Timmermans, Amsterdam, z.j.

Keuning, D. e.a., Verplatting van organisaties, Assen, 1993.

Kerr, C., Industrialism and Industrial Man: The Problems of Labor and Management in Economic Growth, Cambridge, MA, 1960.

Kerr. C., The Future of Industrial Societies, Cambridge, MA 1983.

Kundera, M., Verraden testamenten, Baarn, 1994.

Lafeber, C.V., De Nederlandse Opstand, 1555-1588, Goirle, 1994.

Lammers, C.J., Organisaties vergelijkenderwijs, Utrecht, 1983.

Lammers, C.J., Organiseren van bovenaf en van onderop, Utrecht, 1993.

Roe, R.A., R. Schalk en F. Zijlstra, Veranderingen in arbeid, consequenties voor de arbeids- en organisatiepsychologie, Gedrag en Organisatie, 1995, 8, 209-220.

Said, E.W., Representations of the Intellectual, Reith lectures 1993, London, 1993.

Senge, P.M., The Fifth Discipline, London, 1990/1993.

Senge, P.M. e.a., The Fifth Discipline Fieldbook, New York, 1994.

Sofsky, W., Die Ordnung des Terrors: das Konzentrationslager, Frankfurt am Main, 1993; zie ook Buchheim, H. e.a., Anatomie des SS-Staates, Band 1 en 2, München, 1984.

Vroom, C.W., Het cultuurbegrip in de sociale wetenschappen, in Von Grumbkow, J. (red), Cultuur in organisaties, Assen, 1991.

Whitley, R. (ed.), European Business Systems: Firms and Markets in their National Context, London, 1992.

Whitley, R., Business Systems in East Asia: Firms, Markets and Societies, London, 1992.

Weber, M., Methodologische Schriften, Frankfurt am Main, 1968.

Weber, M., Wissenschaft als Beruf, Politik als Beruf, Studienausgabe, Tübingen, 1994. 